\title{
An Empirical Identification of Performance Gap in Engineering Education Program from the Perspective of Stakeholders
}

\author{
Kaushik Mandal and Chandan Kumar Banerjee
}

\begin{abstract}
Engineering education has become the most sought after destination for the new generation to shape up their future and quality of life. For decades, performance of engineering education is incredible to develop the infrastructural requirement of a country but it should be rejuvenated to meet the challenges of new millennium. The responsibility of engineering educational program is to expose the graduating engineers to industrial experience. Students should be prepared to deal with responsibilities involving planning, design, construction, and maintenance of their built up environment. To succeed in engineering profession, job market requires both strong theoretical base and practical hands-on experience. Industry and academia involvement in engineering education has tremendous potential to facilitate current trends in engineering education, assist in modifying the new curriculum, enhance teaching quality, meet the needs of graduating engineers and their future employers. The performance of engineering education depends on the joint effort of stakeholders. Today, engineering education is thriving through a crucial phase in which performance of this program is under scrutiny. The increasing competition in the field of higher education has compelled the engineering institutions to reevaluate the performance of the program, they offer, to match with the demand of the corporate sector. Performance of an academic program is correlated on the quality dimensions of the same. The present study attempts to enlist various dimensions of quality that affect the performance of an engineering program from stakeholders' point of view. Further, we have identified the perceptual gaps between these stakeholders' vis-à-vis quality dimensions of the academic program. Multivariate tests like Hotelling's trace, Wilks' lambda, Pillai's trace, Roy's largest root have been carried out to identify the said industry-academia gaps. The results help to focus on items, which need immediate attention to lower the gaps and successively enhance the performance of the engineering program. The study suggests that in reforming engineering education a well-balanced and interactive program should be developed, which in turn will benefit both academia and industry and finally to society.
\end{abstract}

Index Terms - Engineering education, performance of the program, industry-academia gap, stakeholders, multivariate analysis, engineering institutions.

\section{INTRODUCTION}

Education is one of the vital service sectors which consists of several stakeholders like, students, their parents; faculty, industry, alumni, society etc. and the expectation of these stakeholders are different. Therefore, measurement of

Manuscript received May 19, 2012; revised July 5, 2012.

The authors are with National Institute of Technology, India (e-mail: chandankbanerjee@gmail.com). performance of educational institutes is quite difficult as the parameters of good performance are varied from stakeholder to stakeholder. However, the quality of an educational institution depends on its overall performance but the measurement of performance is rather difficult then assess of quality. Lockett [1] defined the performance as a multidimensional construct and the common factors that are frequently associated with organizational performance are efficiency, quality, responsiveness, cost, and overall effectiveness. Whereby, Armstrong [2] extend the definition to a performance management as a means of getting better results from the organization, teams and individuals by understanding and managing performance within an agreed framework of planned goals, objectives, and standards of achievement and competence. On the other hand, Neely et al. [3] defined a performance metric as the scope, content, and component parts of a broadly based performance measure. Measurement is the process of quantification and action correlates with performance [4]. Measures can be objective or subjective. Objective measures can be independently measured and verified. Subjective ones cannot [5]. Measurement is a necessary component of evaluation. It gives us data for determining the worth of the object being evaluated [6]. Performance measures must be based on a set of objectives that are linked to the mission of the department and its visions for the future [7]. Pritchard et al. [8] defined performance measures as the numerical or quantitative indicators that show how well each objective is being met. Alternatively, Neely et al., [3] defined a performance measure as a parameter used to quantify the efficiency and / or effectiveness of past action. In their other paper, Neely et al. [9] defined performance measurement as the process of quantifying action, where measurement is the process of quantification and action leads to performance. Therefore, the performance of organizations can be measured by the achievement of their goals such as satisfying their customers need better than their competitors satisfy etc. A successful performance measurement system is a set of performance measure that provides a company with useful information that helps to manage, control, plan and perform the activities undertaken in the company [10]. Tangen [10] also suggested that the performance measures must be designed to reflect the most important factors influencing the productivity of the different processes that can be found in the company. A performance measurement system should be developed for collecting, analyzing and reporting data and information related to the performance of the academic departments [6]. 
In general sense performance is getting the job done and producing the desired result. On the other hand, business performance mmanagement entails reviewing the overall business performance and determining how the business can better reach its goal. Hence, Performance management can be defined as a mechanism to improve organizational performance by linking and aligning individual, team and organizational objectives and results. Service performance is not a very new concept in the field of management. In service sector like education, service performance is considered as the most important benchmark for the overall service quality. Service performance is considered as good when there is no gap or negligible between expected and actual service quality and vice versa. Service performance is measured comparing the expected service with the actual service, where expected service is taken as a standard for this purpose. We can explain the relation as:

Service Performance $=$ No Gap in expected and actual service quality

\section{Where, Service Performance $\longrightarrow$ compared with Benchmark \\ And, Benchmark = Expected Service quality.}

A performance gap exists in education setting when the actual performance is below the planned or expected level of performance. Basically, performance gap is the difference between the actual or present performance and the optimal or expected performance. In a performance analysis, the performance gap $(\mathrm{G})$ can be measured by subtracting the present behavior (B) of the same from the desired standard (S) performance in terms of behavior of the service employees. This measurement, $\mathrm{S}-\mathrm{B}=\mathrm{G}$, becomes the span that must be bridged in order to improve the performance of service setting.

In higher education, the performances of educational institutions are traditionally evaluated according to three major criteria; teaching, research, and services [11]. In Indian higher education sector, engineering is one of the preferred choices for good students at the undergraduate level. The competition for the top institutions is intense with students spending a lot of time and money to get the added advantage for the competitive entrance tests. This demand for engineering has resulted in a mushrooming of a large number of engineering colleges in the country. India has now become a global leader in terms of producing engineering professionals and technocrats in the context of the global technological revolution. The Indian government is now emphasizing more on the development of a knowledge-based economy rather than commodity-based economy for better sustainability. At present India has 2,872 approved degree-level engineering institutes and an intake of 10, 71,896 students, as well as 1,659 approved diplomalevel engineering institutes with an intake of 4,71,006 students [12]. In spite of this, the industry complains of an absence of trained quality engineers and the lack of adequate performance among the fresh engineering graduates are increasing day by day from the industry. Therefore, it is now inevitable to assess the quality of an engineering program to match with the current global industrial requirements.

In this study, we have constricted our focus on the engineering sector of West Bengal, because of the phenomenal development of technical education in this state during the last few years. In West Bengal the entry of the private institutions has vividly changed the facade of engineering education. West Bengal University of Technology (WBUT), which has been established in the year 2001 to broaden the scope of engineering education in the state, has played the role of catalyst in this growth program. WBUT alone has more than 86 engineering institutes, out of which 79 institutes are private and 7 are Government with an intake capacity of 28,100 approximately [13]. Despite the phenomenal growth of engineering education in West Bengal during last 10 years after the introduction of WBUT, the quality of the growth is still under suspicion [14]. This University is the only technical university of the state that affiliates the private engineering institutes. However, the tremendous growth of engineering education in West Bengal during last 10 years has witnessed mushrooming of private engineering institutions in the state. This growing number of private engineering institutions has increased the intake capacity of the students but performance in terms of quality of engineering education provided by these private institutes is yet to be measured.

Therefore, it is imperative to evaluate the performance of engineering program of these institutes to ascertain the quality wise performance of engineering education in the state. In the next section, we have discussed the existing literatures on this issue to pinpoint our research problem.

\section{LITERATURE REVIEW}

\section{A. Service quality}

Service quality is a concept that has aroused considerable interest and debate in the research literature because of the difficulties in both defining it and measuring it with no consensus emerging on either [15]. The perception of service quality has been studied extensively during the past two decades, with most studies being based on the disconfirmation paradigm [16] .There are a number of different definitions as to what is meant by service quality. One that is commonly used defines service quality as the extent to which a service meets customers' needs or expectations [17]-[20]. This definition is very much analogous to the definition of performance gap. Service quality can thus be defined as the difference between customer expectations of service and perceived service. If expectations are greater than performance, then perceived quality is less than satisfactory and hence customer dissatisfaction occurs [21], [17]. Always there exists an important question: how should service quality be measured? Measurement allows for comparison before and after changes, for the location of quality related problems and for the establishment of clear standards for service delivery. Edvardsen et al. [22] state that, in their experience, the starting point in developing quality in services is analysis and measurement. The SERVQUAL approach, 
which is studied in this paper is the most common method for measuring service quality.

There has however been some criticism of the use of the SERVQUAL instrument with a number of researchers debating whether the dimensions of SERVQUAL are consistent across industries with some studies not finding the standard five determinants reported by Parasuraman, Zeithaml and Berry [23], [24]. Others have suggested that the instrument needs better wording for some of the scale items [23], but this was also recognised in the findings of a follow up study undertaken by Parasuraman, Zeithaml and Berry who suggested that wording of the questions need to be tailored to the specific service application, in a language with which respondents can identify [25]. On the other hand, many studies have reported the determinants to be stable across various types of industries [26],[16]. However, the applicability of SERVQUAL scale is questionable in many cases. The main criticism we feel about SERVQUAL scale is related to its questioning to same person (respondent) about expection and perceived actual. It is obvious that either expectation of respondent would affect the perception of respondent or vice-versa and which result in to interaction bias. Validity problems in relation to the measurement of expectations and the practicalities of administering the instrument have also been raised in relation to the SERVQUAL instrument. Cronin and Taylor [24] developed a measurement instrument called SERVPERF, which is a performance only based measure of service quality. The SERVPERF instrument uses an attribute approach to measure customers' experiences of the service. This instrument made use of the original SERVQUAL scales and also allow consumer to rate the provider's service performance with the help of a seven point scale. It uses a single set of questions concerning post consumption perceptions of service quality and does not seek to measure expectations. Taking a single measure of service performance is seen to circumvent the issues of changing customer expectations as well as the need to administer a two part questionnaire each of which were criticisms of the original SERVQUAL instrument [27]

\section{B. Service Quality in Higher Education}

Quality in higher education is a complex and multifaceted concept and a single correct definition of quality is lacking [28]. As a consequence, consensus concerning "the best way to define and measure service quality" [29] does not exist yet. Every stakeholder in higher education (e.g. students, government, professional bodies) has its own view of quality due to particular needs. Students receive and use the training offered by the university, which makes them priority customers of educational activities [30] . Authors such as Sander et al. [31], Gremler and McCollough [32], and Hill [33] also regard students as primary consumers of higher education service. This view, however, does not mean that other perspectives may not be valid and important as well. In this connection, Guolla [34] rightly points out that students could also take the role as clients, producers, and products. Based on findings in the service quality

literature, O"Neill and Palmer [35] define service quality in higher education as "the difference between what a student expects to receive and his/her perceptions of actual delivery". The overriding value in measuring service quality in higher education lies in the identification of critical aspects of the service delivery [36]. However, this presumes a customer-led strategy, whereby the student, as the buyer of the service exchange, is regarded as the customer [37]. It has also been argued that a "customer" metaphor for describing the university service exchange from the perspective of students is unsuitable [38] (Svensson and Wood, 2007). After all, this indirectly frames the academic as the service provider, and thus retracts their immunity from the common marketing axiom: "the customer is always right" [39] (Scott, 1999). It follows that if students cannot be seen as "customers", the measurement of service quality, with the intention of improving the service offering is wholly inappropriate. Some contend this view, suggesting that the acceptance of the student as the "customer" need not negate the power relationship between students and academic staff [39],[40] (Scott, 1999; Sines and Duckworth, 1994). Globalization of higher education has brought competition and which prompted the researchers to focus on quality initiatives [41], [42]. At the education institution perspective, the concept of perceived service quality means students perceived quality because the primary stakeholder of the educational institution is students [43]. Therefore, we could define students' perceived quality is the difference between student evaluation for the services performance level of the educational services provides and service expectation level [44]. Ford et al., [45], have viewed the program in an alternative way and identified reputation, career opportunities, program, physical aspects, and location are the important attributes to form expectation about the service of education service providers. However, the perceived quality is not limited only to the student's perspective, because education service is characterized as a multi-stakeholders segment, which includes students, parents, faculty, alumni, industry, and society. Hence, it is necessary to measure perceived quality from the other stakeholders' point of view as well. A number of researchers have measured service quality from different stakeholders' perspectives [46], [47], because, students are the prime stakeholder in an educational setting and other stakeholders are very much associated with the satisfaction of the students. However, faculty and industry are the two major stakeholders who are directly related to the satisfaction of the students. Faculties are engaged for creating quality of the students and industry are the ultimate accommodator of these quality. Many of these researchers believe that the quality of education largely depends on dimensions like teaching, campus facilities, reputation, physical evidence, administration, urriculum, responsiveness, and recognition [48], [49]. Ahuja et.al. [50], view that curriculum development based on emerging technologies is equally important like faculty development, modernization, and better utilization of infrastructural facilities. They suggest that enhanced exposure of students to industries, feedback system, networking between institutions and institution-industry interaction is crucial dimensions to the overall quality of a program.

This is the point that we also would like to focus. Other authors highlighted that due to high comparative environment surrounding, engineering education institutions 
need to have a better understanding of the nature and quality of service, they offer. Adee [51] recommended several university characteristics, which, may be useful in explaining the perceived quality among students and emphasis on competent teaching, the availability of staff for student consultation, library services, computer facilities, recreational activities, class sizes, level and difficulty of subject content, and student workload. However, few researchers have viewed that the students' satisfaction is not only influenced by the physical facilities, provided by the educational service providers but a well-balanced approach is required towards this direction. Lau [52] suggests a conceptual framework consisting of three factors based on learning, teaching, and resources (Institutional administrators, faculty, and students) which are considered to influence student involvement and satisfaction. Abdullah [36] used HEDPERF instrument consisting of forty-one statements to assess service quality in higher education sector. His study confirmed that students' perceptions of service quality consist of six identified dimensions: nonacademic aspects, academic aspects, reputation, access, program issues, and understanding. Defining quality in higher education has proved to be a challenging task. Cheng and Tam [53] suggest that "education quality is a rather vague and controversial concept" and Pounder [54] argues that quality is a "notoriously ambiguous term". As a result of the difficulty in defining quality, the measurement of quality has also proved to be contentious.

Service quality is strongly associated with the performance of educational institutes. If the service quality of an educational institute is good then the performance of that institute is found to be excellent. Performance measurement in higher education (HE) has seen both major developments and significant continuities. [55]. Ruben [56] suggested that in higher education as in business there are common practice of measuring excellence. Higher education emphasized more on academic measures compare to financial performance. Ruben [56] also indicates that one area deserving greater attention in the process of measurement in higher education is - the student, faculty and staff expectations and satisfaction levels [57]. In the educational sector, each school of faculty need to establish its core competencies based on its mission and vision, besides thinking of its current resources and state of competitiveness [58].

\section{The Dimensions of Service Quality}

Service quality consists of several factors or determinants, which are significant for assessing service quality. A number of researchers have provided lists of quality determinants, but the best known determinants emanate from Parasuraman et.al., who found five dimensions of service quality, namely, tangibles, reliability, responsiveness, assurance and empathy and used these as the basis for their service quality measurement instrument, SERVQUAL [59], [60]. The main concern in decision on developing the dimension of service quality is the range of areas, which should be included in the survey of the research. Different dimensions of service quality used for different industries. However, there are some similarities on the chosen dimensions. Many authors have developed service quality dimensions according to their customers' preferences. Researchers agree that there is no single dimension which can be applicable for all the service sectors [61], [62],[24]. In higher education, a number of researchers have introduced few significant dimensions of service quality. Carney [63] proposed comprehensive nineteen attributes in studying a college's image i.e. student qualification (academic), student qualities (personal), faculty-student interaction, quality instruction (faculty), variety of courses, academic reputation, class size, career preparation, athletic programs, student activities (social life), community service, facilities and equipment, location, physical appearance (campus), on campus residence, friendly, caring atmosphere, religious atmosphere, safe campus, cost/financial aid. Athiyaman [64] used eight characteristics to examine university education services namely, teaching students well, availability of staff for student consultation, library services, computing facilities, recreational facilities, class sizes, level and difficulty of subject content and student workload. Lee et al [65] explained that the two of the total quality experience variables 'overall impression of the school' and 'overall impression of the education quality' are the determinant variables in predicting the overall satisfaction.

Al though previous researchers have pointed out several dimensions for quality in higher education, but among them academic programme or programme is the most important, because it is the ultimate parameter for a student for selecting an institute for higher education [66], [67]. It is found to be one of the common dimensions. This dimension of higher education is our focal point Other dimensions like infrastructure, physical facility, hostel facilities etc. are secondary in comparison to this dimension.. However, the collaboration between academia and industry is important for determining the quality of an academic program as well as an educational institute [68]. Further, it is important to validate and review the existing program of an educational institute time to time to keep pace with the changing requirement of technology [69]. Mandal and Banerjee [70] have developed a reliable and valid construct for measuring the quality of engineering and technology program in the Indian context. The researchers have identified "degree of industry focus ness of the program", "quality related to program and pedagogy" and "degree of industry readiness of the program" as three important dimensions for measuring the quality of an academic program. According to them, an ideal program should be industry oriented and should be capable enough to fulfill the requirement and demand of the industry. They feel that the quality of an academic program is largely depending on the quality of its pedagogy.

A thorough study on the existing literatures regarding this issue exposes that the dimensions of a quality engineering program has never been identified from the academia industry and students point of view but empirically not tested, even though they are the principal stakeholders of engineering education. Therefore, there is a necessity to conduct further investigation in order to find out the perceptual gap between these stakeholders regarding 
dimensions of an ideal engineering program. However, in this research we are employing the reliable and valid construct of Mandal and Banerjee [70] to investigate the issue.

\section{RESEARCH PROBlem AND Hypothesis}

As per the construct developed by Mandal and Banerjee [70], each of these factors consists of some items. We have recorded the responses of students, industry executives and faculties of the engineering institutes for each of the item (Table 1). For analysis, we have considered responses for all items under each of the factors as a vector combination and thus treat each factor as a vector for each of the three groups of respondent i.e. students, executives and faculties. Hence, we were in a position to compare the vector means between the said three groups. This research query helped us to develop three sets of hypothesis. Each of the three sets consists of two hypothesis and all of these six hypothesis we can write in a general format of hypothesis entry notation, which are as follows:

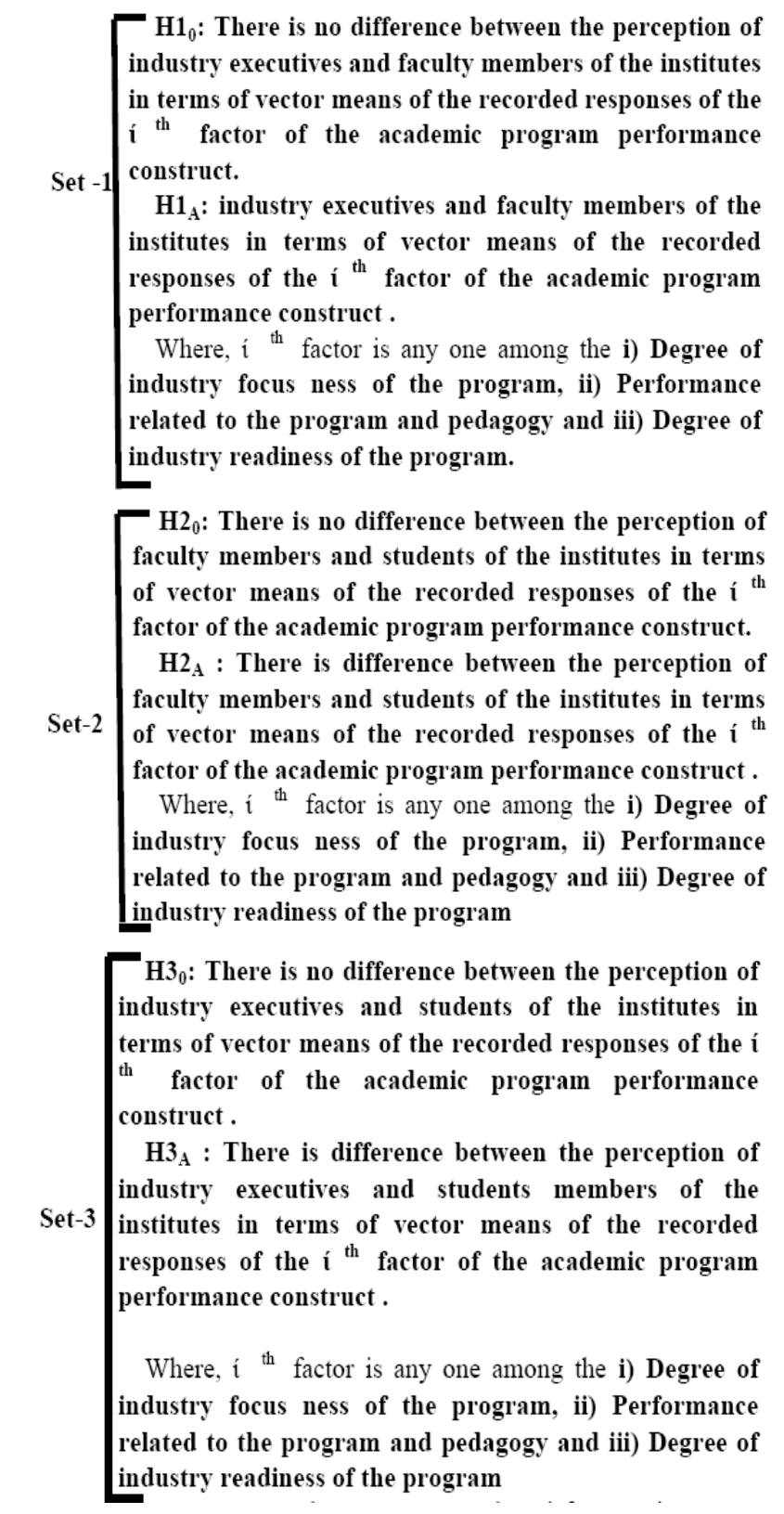

$\mathrm{H1}_{0}$ : There is no difference between the perception of industry executives and faculty members of the institutes in terms of vector means of the recorded responses of the $i^{\text {th }}$ factor of the academic program performance construct.

$\mathrm{H} 1_{\mathrm{A}}$ : ind institutes in terms of vector means of the recorded responses of the $i^{\text {th }}$ factor of the academic program performance construct . related to the program and pedagogy and iii) Degree of of vector means of the recorded responses of the $i$ factor of the academic program performance construct. factor of the academic program performance construct . Where, $i^{\text {th }}$ factor is any one among the i) Degree of Werty focus mess of the program, ii) Performance related to the program and pedagogy and iii) Degree of erms of vector means of the recorded responses of the $i$ factor of the academic program performance construct institutes in terns of vector means of the recorded responses of the $i^{\text {th }}$ factor of the academic program performance construct .

Where, $i^{\text {th }}$ factor is any one among the i) Degree of related to the program and pedagogy and iii) Degree of industry readiness of the program
However, we have to test and satisfy two important conditions for carrying out these hypotheses. Despite of the fact, that when the original construct have been developed, the researchers extract factors from the item, based on their inter correlation, still we have to check empirically that whether the items under each factor is correlated ideally to be used as vector combinations or not. If the result is positive then only we can proceed further for any hypothesis, which refer for multivariate ' $t$ ' test. Subsequently, we have to be sure about the performance of variance-covariance matrices of the two populations considered in the present study. If these conditions are satisfied then only we proceed for mentioned hypothesis, which is dealing with variables with multivariate nature.

\section{Methodology}

An extensive literature study was conducted on performance management and service quality in educational settings with a particular focus on performance gap. Furthermore, a quantitative empirical design was used for the research.

\section{A. Sample and Procedures}

We have selected the state of West Bengal for conducting present research, because, in the recent past the state has experienced enormous growth of private engineering colleges and the performance of the education service, provided by these colleges is in question. As we would like to focus only on private engineering education, we have chosen WBUT for determining the population, from which we selected the each sample unit randomly. We have used pack of card; each has been specified with identification of private engineering colleges under WBUT. We have chosen 12 private engineering institutes randomly. Then, we prepared a single list of faculty with more than 10 years of experience from the pool of engineering institutes. We have contacted with 150 faculties and finally received responses from 129 faculties. In the same way, we have randomly selected 11 industries from the pool of industries, who frequently visit the college campuses of these private engineering colleges for selecting students through campus interview. We have prepared a final list of executives with more than 10 years of experience from the pool of industry. Out of 200 executives, whom we have contacted, we have collected responses from 131 executives. Finally, we have made a list of first year, second year and third year from all the twelve engineering institutes and randomly selected 147 students from the pool of students. Hence, a total of 407 $(129+131+147)$ valid responses are taken into consideration for further analysis.

\section{B. Statistical tools used to study the hypothesis}

In the present research, we have dealt with a hypothesis and two generalized conditions in each of three cases. These two conditions are used as necessary conditions for carrying out the hypothesis. For testing the hypothesis, we may use any of the multivariate ' $t$ ' test, like Hotelling's trace, Wilks' lambda, Pillai's trace, Roy's largest root (definitions are given in the appendix). All of these are used for comparing vector mean between two populations. However, for 
carrying out the hypothesis we need to satisfy condition 1 and 2 in three cases. For checking condition 1, we have to run 'Barlett's test of spherecity' and for satisfying condition
2, we have to carry out Box's M test statistics (see appendix for description).

TABLE I: DESCRIPTIVE STATISTICS FOR INDUSTRY EXECUTIVES AND FACULTY

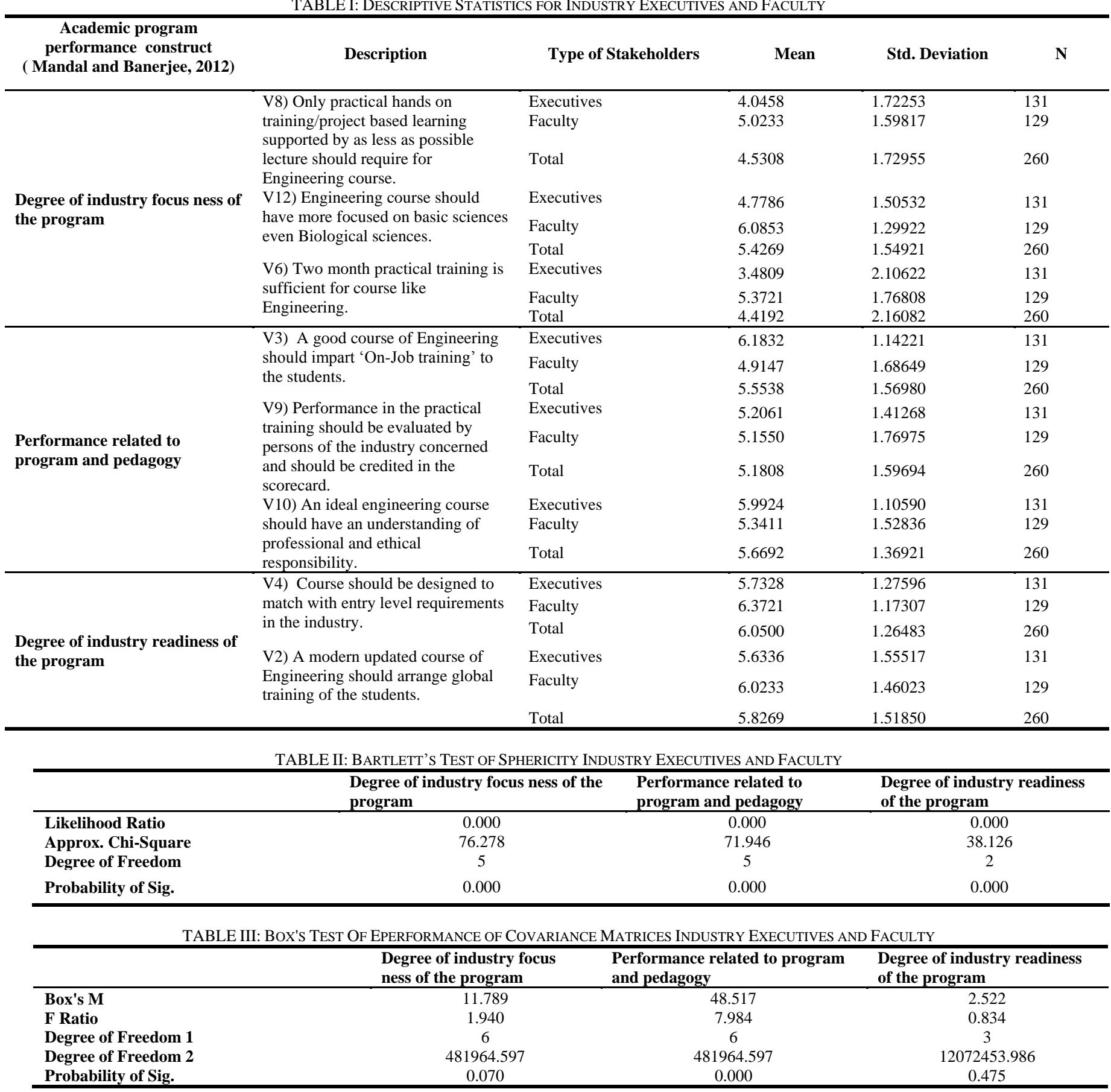

\section{ANALYSIS AND FINDINGS}

We have carried out various multivariate tests to identify whether the views of three stakeholders are different on the dimensions of an ideal engineering program or not.

Table 4 explains the four most commonly used multivariate tests for comparing vector means of two populations (Pillai's trace, Wilks' lambda, Hotelling's trace \& Roy's largest root). The criterion of significance of each of these tests is assumed 0.05 . If probability value is less than 0.05 then the null hypothesis is rejected. The results of multivariate tests show that all the probability value is less than $0.05(<0.05)$. Thus, the null hypothesis $\left(\mathbf{H 1}_{\mathbf{0}}\right)$ is rejected and the alternative hypothesis $\left(\mathbf{H 1} \mathbf{1}_{\mathbf{A}}\right)$, which assumes difference in vector mean scores between the faculty and the executives, are accepted. It indicates that the group differences present between faculty and industry executives.

Table 4, describes that all the three performance dimensions of an ideal engineering program i.e. Degree of industry focus ness of the program, Performance related to program and pedagogy and Degree of industry readiness of the program are holding the significant probability criterion in relation to an ideal engineering program. Each of these 
four tests indicates that for these three factors there is a significant difference between the faculty and industry executives regarding the performance of an ideal engineering program. The result of the test confirms that the perceptual gap exists between the two groups, faculty, and industry executives, regarding all these three dimensions of performance of an ideal engineering program.

In the second phase, we have analysed the view of faculty and students. Table 5 provides a summary of the second group profiles on each of the items of performance dimension between the faculty and students.

TABLE IV: MUlTIVARIATE TESTS FOR INDUSTRY EXECUTIVES AND FACULTY

\begin{tabular}{|c|c|c|c|c|c|c|c|}
\hline $\begin{array}{l}\text { Dimensions of } \\
\text { program performance }\end{array}$ & Tests & Value & $\mathrm{F}$ & $\begin{array}{l}\text { Hypo } \\
\text { thesis df }\end{array}$ & $\begin{array}{l}\text { Error } \\
\text { df }\end{array}$ & Sig. & $\begin{array}{l}\text { Rem } \\
\text { arks }\end{array}$ \\
\hline \multirow{4}{*}{$\begin{array}{l}\text { Degree of industry } \\
\text { focus ness of the } \\
\text { program }\end{array}$} & Pillai's trace & 0.266 & 30.898 & 3.000 & 256.000 & 0.000 & \multirow{4}{*}{ Gap exists } \\
\hline & Wilks' lambda & 0.734 & 30.898 & 3.000 & 256.000 & 0.000 & \\
\hline & Hotelling's trace & 0.362 & 30.898 & 3.000 & 256.000 & 0.000 & \\
\hline & Roy's largest root & 0.362 & 30.898 & 3.000 & 256.000 & 0.000 & \\
\hline \multirow{4}{*}{$\begin{array}{l}\text { Performance related } \\
\text { to program and } \\
\text { pedagogy }\end{array}$} & Pillai's trace & 0.176 & 18.240 & 3.000 & 256.000 & 0.000 & \multirow{4}{*}{ Gap exists } \\
\hline & Wilks' lambda & 0.824 & 18.240 & 3.000 & 256.000 & 0.000 & \\
\hline & Hotelling's trace & 0.214 & 18.240 & 3.000 & 256.000 & 0.000 & \\
\hline & Roy's largest root & 0.214 & 18.240 & 3.000 & 256.000 & 0.000 & \\
\hline \multirow{4}{*}{$\begin{array}{l}\text { Degree of industry } \\
\text { readiness of the } \\
\text { program }\end{array}$} & Pillai's trace & 0.066 & 9.114 & 2.000 & 257.000 & 0.000 & \multirow{4}{*}{ Gap exists } \\
\hline & Wilks' lambda & 0.934 & 9.114 & 2.000 & 257.000 & 0.000 & \\
\hline & Hotelling's trace & 0.071 & 9.114 & 2.000 & 257.000 & 0.000 & \\
\hline & Roy's largest root & 0.071 & 9.114 & 2.000 & 257.000 & 0.000 & \\
\hline
\end{tabular}

TABLE V: DESCRIPTIVE STATISTICS FOR FACULTY AND STUDENTS

\begin{tabular}{|c|c|c|c|c|c|}
\hline $\begin{array}{c}\text { Academic program } \\
\text { performance construct } \\
\text { ( Mandal and Banerjee, } \\
\text { 2012) }\end{array}$ & Description & $\begin{array}{c}\text { Type of } \\
\text { Stakeholders }\end{array}$ & Mean & Std. Deviation & \\
\hline \multirow{9}{*}{$\begin{array}{l}\text { Degree of industry focus } \\
\text { ness of the program }\end{array}$} & \multirow{6}{*}{$\begin{array}{l}\text { V8) Only practical hands on } \\
\text { training/project based learning supported } \\
\text { by as less as possible lecture should require } \\
\text { for Engineering course. } \\
\text { V12) Engineering course should have more } \\
\text { focused on basic sciences even Biological } \\
\text { sciences. }\end{array}$} & Faculty & 5.0233 & 1.59817 & 129 \\
\hline & & students & 5.0408 & 1.76293 & 147 \\
\hline & & Total & 5.0326 & 1.68491 & 276 \\
\hline & & Faculty & 6.0853 & 1.29922 & 129 \\
\hline & & students & 4.3946 & 1.72634 & 147 \\
\hline & & Total & 5.1848 & 1.75559 & 276 \\
\hline & \multirow{3}{*}{$\begin{array}{l}\text { V6) Two month practical training is } \\
\text { sufficient for course like Engineering. }\end{array}$} & Faculty & 5.3721 & 1.76808 & 129 \\
\hline & & students & 5.3537 & 1.69125 & 147 \\
\hline & & Total & 5.3623 & 1.72444 & 276 \\
\hline \multirow{9}{*}{$\begin{array}{l}\text { Performance related to } \\
\text { program and pedagogy }\end{array}$} & \multirow{2}{*}{$\begin{array}{l}\text { V3) A good course of Engineering should } \\
\text { impart 'On-Job training' to the students. }\end{array}$} & Faculty & 4.9147 & 1.68649 & 129 \\
\hline & & students & 6.3673 & 1.23356 & 147 \\
\hline & \multirow{7}{*}{$\begin{array}{l}\text { V9) Performance in the practical training } \\
\text { should be evaluated by persons of the } \\
\text { industry concerned and should be credited } \\
\text { in the scorecard. } \\
\text { V10) An ideal engineering course should } \\
\text { have an understanding of professional and } \\
\text { ethical responsibility. }\end{array}$} & Total & 5.6884 & 1.63062 & 276 \\
\hline & & Faculty & 5.1550 & 1.76975 & 129 \\
\hline & & students & 5.2041 & 1.67143 & 147 \\
\hline & & Total & 5.1812 & 1.71511 & 276 \\
\hline & & Faculty & 5.3411 & 1.52836 & 129 \\
\hline & & students & 4.3469 & 1.97121 & 147 \\
\hline & & Total & 4.8116 & 1.84312 & 276 \\
\hline \multirow{6}{*}{$\begin{array}{l}\text { Degree of industry } \\
\text { readiness of the program }\end{array}$} & \multirow{3}{*}{$\begin{array}{l}\text { V4) Course should be designed to match } \\
\text { with entry level requirements in the } \\
\text { industry. }\end{array}$} & Faculty & 6.3721 & 1.17307 & 129 \\
\hline & & students & 5.7211 & 1.41316 & 147 \\
\hline & & Total & 6.0254 & 1.34411 & 276 \\
\hline & \multirow{3}{*}{$\begin{array}{l}\text { V2) A modern updated course of } \\
\text { Engineering should arrange global training } \\
\text { of the students. }\end{array}$} & Faculty & 6.0233 & 1.46023 & 129 \\
\hline & & students & 5.1361 & 1.52441 & 147 \\
\hline & & Total & 5.5507 & 1.55656 & 276 \\
\hline
\end{tabular}

Table 5 reveals that there is a difference in mean scores among item of each performance dimension between the two groups of stakeholders. Table 6 , reveals the results of Barlett's test of sphericity for the two groups faculty and students. The probability value of significance of the test is found to be 0.000 . Hence, it is clear that the items under each specified factor are having multivariate character. As a result, they ought to be articulated as vector combination. This test is an important precondition for multivariate test.

Table 7, shows that the results of the Box's M test is > 0.05 , which indicates the acceptance of the null hypothesis
(H2 $)_{0}$ that assuming no difference in variance covariance matrices for two populations.

For almost all the factors, same results are found. Therefore, we conclude that condition 2 is satisfied for carrying out multivariate tests for vector means of two populations.

Finally, we have analysed the view of industry executives and students. Table 9 provides a summary of the third group profiles on each of the items of performance dimension between the industry executives and students. Table 9 reveals that there is a difference in mean scores among item of each performance dimension between the two groups of stakeholders. 
TABLE VI: BARTLETT'S TEST OF SPHERICITY FOR FACULTY AND STUDENTS

\begin{tabular}{lccc}
\hline & $\begin{array}{c}\text { Degree of industry focus } \\
\text { ness of the program }\end{array}$ & $\begin{array}{c}\text { Performance related to } \\
\text { program and pedagogy }\end{array}$ & $\begin{array}{c}\text { Degree of industry } \\
\text { readiness of the program }\end{array}$ \\
\hline Likelihood Ratio & 0.000 & .000 & 0.004 \\
Approx. Chi-Square & 90.342 & 30.635 & 11.106 \\
Degree of Freedom & 5 & 5 & 2 \\
Probability of Sig. & 0.000 & .000 & .004 \\
\hline
\end{tabular}

TABLE VII: BOX'S TEST OF EPERFORMANCE OF COVARIANCE MATRICES FOR FACULTY AND STUDENTS

\begin{tabular}{lccc}
\hline & $\begin{array}{l}\text { Degree of industry } \\
\text { focus ness of the } \\
\text { program }\end{array}$ & $\begin{array}{l}\text { Performance related to } \\
\text { program and pedagogy }\end{array}$ & $\begin{array}{l}\text { Degree of industry } \\
\text { readiness of the program }\end{array}$ \\
\hline Box's M & 13.510 & 31.213 & 8.707 \\
F Ratio & 2.225 & 5.140 & 2.879 \\
Degree of Freedom 1 & 6 & 6 & 3 \\
Degree of Freedom 2 & 519734.924 & 519734.924 & 29687738.347 \\
Probability of Sig. & 0.068 & 0.000 & .065 \\
\hline
\end{tabular}

TABLE VIII: MULTIVARIATE TESTS FOR FACULTY AND STUDENTS

\begin{tabular}{|c|c|c|c|c|c|c|c|}
\hline $\begin{array}{l}\text { Dimensions of } \\
\text { program } \\
\text { performance }\end{array}$ & Tests & Value & $\mathbf{F}$ & $\begin{array}{l}\text { Hypothe } \\
\text { sis df }\end{array}$ & Error df & Sig. & Remarks \\
\hline \multirow{4}{*}{$\begin{array}{l}\text { Degree of industry } \\
\text { focus ness of the } \\
\text { program }\end{array}$} & Pillai's trace & 0.101 & 10.175 & 3.000 & 271.000 & 0.000 & \multirow{4}{*}{ Gap exists } \\
\hline & Wilks' lambda & 0.899 & 10.175 & 3.000 & 271.000 & 0.000 & \\
\hline & Hotelling's trace & 0.113 & 10.175 & 3.000 & 271.000 & 0.000 & \\
\hline & Roy's largest root & 0.113 & 10.175 & 3.000 & 271.000 & 0.000 & \\
\hline \multirow{3}{*}{$\begin{array}{l}\text { Performance related } \\
\text { to program and } \\
\text { pedagogy }\end{array}$} & Pillai's trace & .277 & 34.618 & 3.000 & 271.000 & .000 & \multirow{3}{*}{ Gap exists } \\
\hline & Wilks' lambda & .723 & 34.618 & 3.000 & 271.000 & .000 & \\
\hline & $\begin{array}{l}\text { Hotelling's trace } \\
\text { Roy's largest root }\end{array}$ & $\begin{array}{l}.383 \\
.383\end{array}$ & $\begin{array}{l}34.618 \\
34.618\end{array}$ & $\begin{array}{l}3.000 \\
3.000\end{array}$ & $\begin{array}{l}271.000 \\
271.000\end{array}$ & $\begin{array}{l}.000 \\
.000\end{array}$ & \\
\hline \multirow{4}{*}{$\begin{array}{l}\text { Degree of industry } \\
\text { readiness of the } \\
\text { program }\end{array}$} & Pillai's trace & .054 & 7.809 & 2.000 & 272.000 & .001 & \multirow{4}{*}{ Gap exists } \\
\hline & Wilks' lambda & .946 & 7.809 & 2.000 & 272.000 & .001 & \\
\hline & Hotelling's trace & .057 & 7.809 & 2.000 & 272.000 & .001 & \\
\hline & Roy's largest root & .057 & 7.809 & 2.000 & 272.000 & .001 & \\
\hline
\end{tabular}

TABLE IX: DESCRIPTIVE STATISTICS FOR INDUSTRY EXECUTIVES AND STUDENTS

zAcademic program
performance construct
( Mandal and Banerjee,
2012)

\begin{tabular}{|c|c|c|c|c|c|}
\hline \multirow{9}{*}{$\begin{array}{l}\text { Degree of industry focus } \\
\text { ness of the program }\end{array}$} & \multirow{3}{*}{$\begin{array}{l}\text { V8) Only practical hands on } \\
\text { training/project based learning } \\
\text { supported by as less as possible } \\
\text { lecture should require for Engineering } \\
\text { course. }\end{array}$} & Executives & 4.0458 & 1.72253 & 131 \\
\hline & & students & 5.0408 & 1.76293 & 147 \\
\hline & & Total & 4.5719 & 1.81058 & 278 \\
\hline & \multirow{3}{*}{$\begin{array}{l}\text { V12) Engineering course should have } \\
\text { more focused on basic sciences even } \\
\text { Biological sciences. }\end{array}$} & Executives & 4.7786 & 1.50532 & 131 \\
\hline & & students & 4.3946 & 1.72634 & 147 \\
\hline & & Total & 4.5755 & 1.63437 & 278 \\
\hline & \multirow{3}{*}{$\begin{array}{l}\text { V6) Two month practical training is } \\
\text { sufficient for course like Engineering. }\end{array}$} & Executives & 3.4809 & 2.10622 & 131 \\
\hline & & students & 5.3537 & 1.69125 & 147 \\
\hline & & Total & 4.4712 & 2.11345 & 278 \\
\hline \multirow{9}{*}{$\begin{array}{l}\qquad \text { Performance } \\
\text { related to program and } \\
\text { pedagogy }\end{array}$} & \multirow{3}{*}{$\begin{array}{l}\text { V3) A good course of Engineering } \\
\text { should impart 'On-Job training' to the } \\
\text { students. }\end{array}$} & Executives & 6.1832 & 1.14221 & 131 \\
\hline & & students & 6.3673 & 1.23356 & 147 \\
\hline & & Total & 6.2806 & 1.19281 & 278 \\
\hline & $\begin{array}{l}\text { V9) Performance in the practical } \\
\text { training should be evaluated by }\end{array}$ & Executives & 5.2061 & 1.41268 & 131 \\
\hline & \multirow{2}{*}{$\begin{array}{l}\text { persons of the industry concerned and } \\
\text { should be credited in the scorecard. }\end{array}$} & students & 5.2041 & 1.67143 & 147 \\
\hline & & Total & 5.2050 & 1.55212 & 278 \\
\hline & \multirow{3}{*}{$\begin{array}{l}\text { V10) An ideal engineering course } \\
\text { should have an understanding of } \\
\text { professional and ethical responsibility. }\end{array}$} & Executives & 5.9924 & 1.10590 & 131 \\
\hline & & students & 4.3469 & 1.97121 & 147 \\
\hline & & Total & 5.1223 & 1.81633 & 278 \\
\hline \multirow{6}{*}{$\begin{array}{l}\text { Degree of industry } \\
\text { readiness of the program }\end{array}$} & \multirow{3}{*}{$\begin{array}{l}\text { V4) Course should be designed to } \\
\text { match with entry level requirements in } \\
\text { the industry. }\end{array}$} & Faculty & 6.3721 & 1.17307 & 129 \\
\hline & & students & 5.7211 & 1.41316 & 147 \\
\hline & & Total & 6.0254 & 1.34411 & 276 \\
\hline & \multirow{3}{*}{$\begin{array}{l}\text { V2) A modern updated course of } \\
\text { Engineering should arrange global } \\
\text { training of the students. }\end{array}$} & Faculty & 6.0233 & 1.46023 & 129 \\
\hline & & students & 5.1361 & 1.52441 & 147 \\
\hline & & Total & 5.5507 & 1.55656 & 276 \\
\hline
\end{tabular}


Table 10, discloses the results of Barlett's test of sphericity for the two groups industry executives and students. The probability value of significance of the test is found to be 0.000 . Hence, it is clear that the items under each specified factor are having multivariate character. As a result, they ought to be expressed as vector combination.

Table 11, shows that the results of the Box's $M$ test is $>$ 0.05 , which indicates the acceptance of the null hypothesis
$\left(\mathbf{H 3}_{\mathbf{0}}\right)$ that assuming no difference in variance covariance matrices for two populations. For almost all the factors, same results are found. Therefore, we conclude that condition 2 is satisfied for carrying out multivariate tests for vector means of two populations.

TABLE X: BARTLETT'S TEST OF SPHERICITY FOR INDUSTRY EXECUTIVES AND STUDENTS

\begin{tabular}{|c|c|c|c|}
\hline & $\begin{array}{l}\text { Degree of industry focus } \\
\text { ness of the program }\end{array}$ & $\begin{array}{l}\text { Performance related to } \\
\text { program and pedagogy }\end{array}$ & $\begin{array}{l}\text { Degree of industry readiness of } \\
\text { the program }\end{array}$ \\
\hline Likelihood Ratio & 0.000 & .000 & 0.004 \\
\hline Approx. Chi-Square & 185.280 & 64.638 & 11.106 \\
\hline Degree of Freedom & 5 & 5 & 2 \\
\hline \multicolumn{4}{|l|}{ Probability of Sig. } \\
\hline & $\begin{array}{l}\text { Degree of industry focus } \\
\text { ness of the program }\end{array}$ & $\begin{array}{l}\text { Performance related to } \\
\text { program and pedagogy }\end{array}$ & $\begin{array}{l}\text { Degree of industry readiness } \\
\text { of the program }\end{array}$ \\
\hline Box's M & 20.699 & 73.319 & 8.707 \\
\hline F Ratio & 3.409 & 12.075 & 2.879 \\
\hline Degree of Freedom 1 & 6 & 6 & 3 \\
\hline Degree of Freedom 2 & 532625.731 & 532625.731 & 29687738.347 \\
\hline Probability of Sig. & .052 & .054 & .065 \\
\hline
\end{tabular}

The results of all four multivariate tests (Table 12), show that all the probability value is less than $0.05(<0.05)$. Thus, the null hypothesis $\left(\mathbf{H 3}_{\mathbf{0}}\right)$ is rejected and the alternative hypothesis $\left(\mathbf{H} \mathbf{3}_{\mathrm{A}}\right)$, which assumes difference in vector mean scores between industry executives and students are accepted. It disclose that there are group differences between industry executives and students.

TABLE XII: MUlTIVARIATE TESTS FOR INDUSTRY EXECUTIVES AND STUDENTS

\begin{tabular}{|c|c|c|c|c|c|c|c|}
\hline $\begin{array}{l}\text { Dimensions of } \\
\text { program } \\
\text { performance }\end{array}$ & Tests & Value & $\mathbf{F}$ & $\begin{array}{c}\text { Hypothesis } \\
\text { df }\end{array}$ & Error df & Sig. & Remarks \\
\hline \multirow{4}{*}{$\begin{array}{l}\text { Degree of industry } \\
\text { focus ness of the } \\
\text { program }\end{array}$} & Pillai's trace & .133 & 14.018 & 3.000 & 273.000 & .000 & \multirow{4}{*}{ Gap exists } \\
\hline & Wilks' lambda & .867 & 14.018 & 3.000 & 273.000 & .000 & \\
\hline & Hotelling's trace & .154 & 14.018 & 3.000 & 273.000 & .000 & \\
\hline & Roy's largest root & .154 & 14.018 & 3.000 & 273.000 & .000 & \\
\hline \multirow{4}{*}{$\begin{array}{l}\text { Performance } \\
\text { related to program } \\
\text { and pedagogy }\end{array}$} & Pillai's trace & .186 & 20.796 & 3.000 & 273.000 & .000 & \multirow{4}{*}{ Gap exists } \\
\hline & Wilks' lambda & .814 & 20.796 & 3.000 & 273.000 & .000 & \\
\hline & Hotelling's trace & .229 & 20.796 & 3.000 & 273.000 & .000 & \\
\hline & Roy's largest root & .229 & 20.796 & 3.000 & 273.000 & .000 & \\
\hline \multirow{4}{*}{$\begin{array}{l}\text { Degree of industry } \\
\text { readiness of the } \\
\text { program }\end{array}$} & Pillai's trace & .054 & 7.809 & 2.000 & 272.000 & .001 & \multirow{4}{*}{ Gap exists } \\
\hline & Wilks' lambda & .946 & 7.809 & 2.000 & 272.000 & .001 & \\
\hline & Hotelling's trace & .057 & 7.809 & 2.000 & 272.000 & .001 & \\
\hline & Roy's largest root & .057 & 7.809 & 2.000 & 272.000 & .001 & \\
\hline
\end{tabular}

\section{MODEL BASED GAP ANALYSIS}

From the statistical analysis, it is quite clear that there are few significant gaps between faculty, students, and industry regarding the performance of an ideal engineering program. From these perceptual gaps between the stakeholders, a conceptual model (Fig. 1) has been developed by which we can explain the gaps between the stakeholders. To do that, they must understand the performance attributes embraced by these students because performance is perceived differently.

From the below model (Fig 1), it is obvious that Students, faculty and industry are the three major stakeholders of engineering education. In higher education sector like engineering, institutes deploy resources for the faculty for providing quality education to the students and at the same time faculty impart training to students in order to make them ready for the industry. The students are paying the requisite fee for their education and training. On the other hand, faculty learns how to prepare students as per the need and requirement of the industry as because it is the ultimate aim for any professional educational institute. Students prepare themselves through the education and training to fulfill the criteria of recruitment. Finally, industry recruits the students who possess adequate knowledge in both theoretical and practical subjects. 


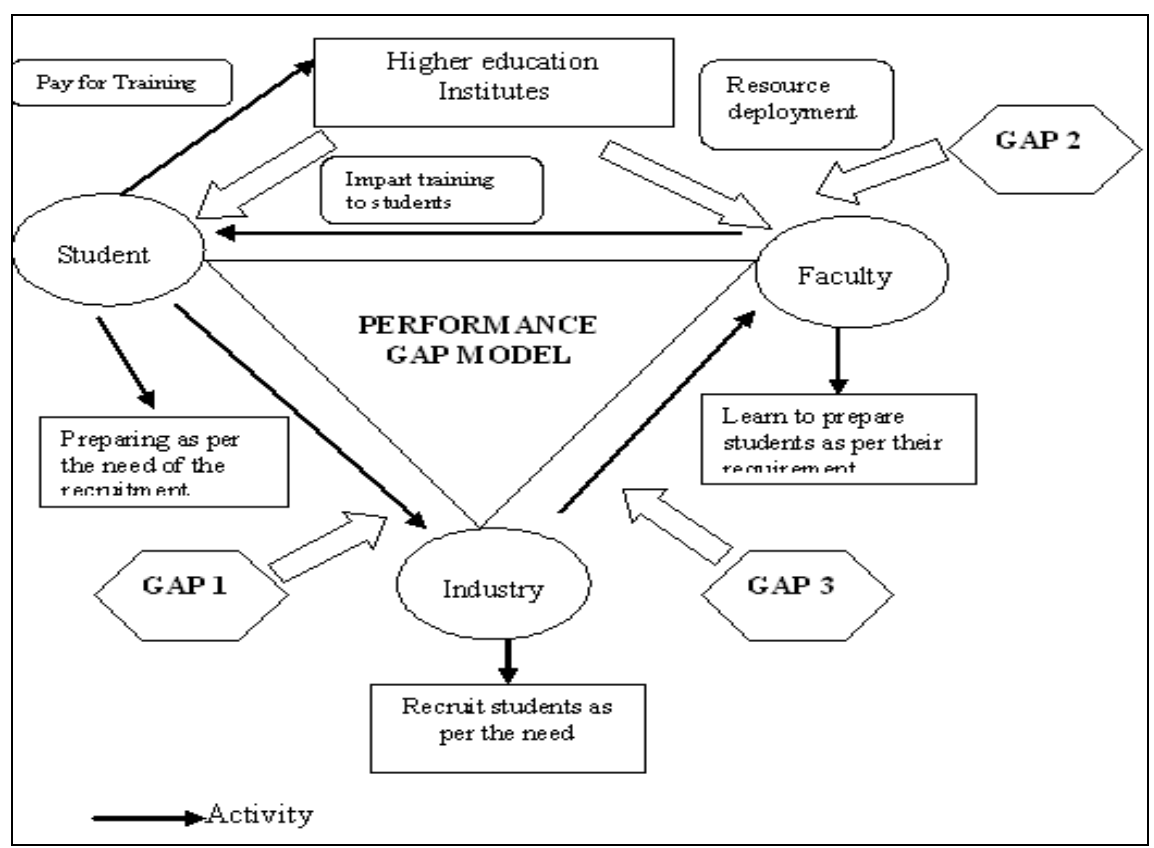

Fig. 1. Performance Gap Model.

TABLE XIII : GAP AMONG THE STAKEHOLDERS

\begin{tabular}{|c|c|c|c|}
\hline Dimensions & Faculty Mean & Students Mean & Industry Mean \\
\hline $\begin{array}{c}\text { Degree of industry focus ness } \\
\text { of the program }\end{array}$ & 5.4935 & 4.9297 & 4.1017 \\
\hline $\begin{array}{c}\text { Performance related to } \\
\text { program and pedagogy }\end{array}$ & 5.1369 & 5.3061 & 5.7939 \\
\hline $\begin{array}{c}\text { Degree of industry readiness } \\
\text { of the program }\end{array}$ & 6.1977 & 5.4286 & 5.6832 \\
\hline
\end{tabular}

From the above Table ( Table 13), it can be observed that in case of the first dimension, "Degree of industry focusness of the program", the mean value of industry is lower than faculty and students because, the planning of faculty and students for the industry focusness of the program is higher than the industry. In this stage faculty and students plan to perform more than the expectation of the industry. Therefore, a positive gap has been observed here. In case of second dimension, "Performance related to program and pedagogy", we can observe that, the expectation of industry is higher than faculty and students. The industry expects better performance of the engineering program and pedagogy where as the students and faculty expectation is lower. It indicates that the execution of the engineering program is not at par with the expectation of the industry. Hence, a gap among faculty, students and industry is observed Further, in the third dimension ," Degree of industry readiness of the program", we can observe that there is a significant gap between faculty and students. This gap occurs because; faculty fails to execute, what they know about the industry readiness of the program, to the students. The failure of the faculty causes the gap between industry expectation and actual supply of output. Other reason for this gap might be the lack of interaction between the faculty and industry regarding the ideal performance parameter of an engineering program.

\section{RECOMMENDATIONS}

From the backdrop of the study it is quite clear that there is need to take few corrective measures to bridge the gap among the stakeholders. This paper suggests following recommendations to bridge the gap among these three groups of stakeholders, faculty, and executives in order to strengthen the bonding between academia and industry as a whole. :a) Industries should participate actively in the workshop, laboratories and practical program of engineering institutes to enhance the performance of engineering program. b) Academia-industry cooperation in the areas of research and development of engineering program is needed which can help both the students and faculties to get the experience of establishing turn key projects, plants etc. which in turn will enhance their practical knowledge as well. c) Implementation of the two-way training program for both faculty and industry executives is necessary for better understanding of engineering program. d) Engineering institutes should consider the view of the students in order to enhance their performance. e) Adequate industrial training facility and on-the-job training facility are to be provided to the students for their better industrial exposure. f) Performance management system of the engineering institutes must be evaluate periodically to improve the performance. g) Performance of the engineering program should also be assessed by the academic and industry experts time to time in order to make it better and more relevant as per the need of the industry. 


\section{CONCLUSION}

In this research, we have found that there are significant gaps between these three groups of stakeholders regarding the essential performance dimensions of an ideal engineering program. Though the model proposed by Mandal and Banerjee [36] require more customize application for the better implementation of this model still it is a landmark in this segment to measure the performance of an academic program. However, this research reveals that there are few significant differences among faculty industry executives and students regarding the performance of an engineering program.

\section{APPENDIX: DESCRIPTION OF STATISTICAL TOOLS USED:}

Box's M test statistics: Box $M$ test statistics is used to measure whether variance-covariance matrices of the two or more than two populations are equal or not. If they are found to be unequal, multivariate test procedure is become inoperative. Therefore, it is imperative to check the eperformance of variance-covariance matrices for two and more than two populations (Andy Filed 2009).

Barlett's test of spherecity: Barlett's test of spherecity tests whether residual covariance matrix is different from identity matrix or not. Identity matrix is the symbol of perfect multivariate nature. If the matrix is not different from matrix, it means that the data is multivariate in nature (Andy Filed 2009).

Pillai's trace: it is the sum of the proportion of explained variance on the discriminant variates of the data. Statistics is used to test difference in vector mean between two populations. (Andy Filed 2009). Desired Value is $\mathrm{p}<0.05$. Pillai's Trace $=\mathrm{V}=\sum_{i=1}^{n} \frac{\lambda_{i}}{1+\lambda_{i}}$,

Wilks' lambda: It is the product of the unexplained variance on eachof the discriminate function variates. It represents the ratio of error variance to total variance for each variate. Statistics is used to test difference in vector mean between two populations. Desired Value is $p<0.05$.

$$
\text { Wilks' Lambda }=\Lambda=\prod_{i=1}^{n} \frac{1}{1+\lambda i}
$$

Hotelling's trace: 'Hotelling Trace' is the sum of eigenvalue for each discriminant function variate of the data. It is the sum of the ratio of systematic and unsystematic variance for each of the variates. Statistics is used to test difference in vector mean between two populations. (Andy Filed 2009) Desired Value is $\mathrm{p}<0.05$. Hotelling's Trace $=\mathrm{T}=\sum_{i=1}^{n} \lambda_{i}$

Roy's largest root: It is the eigenvalue for the first discrminat function variate of a set of observation. It represents the proportion of explained variance to unexplained variance. Statistics is used to test difference in ve ctor mean between two populations. Desired Value is $\mathrm{p}<0.05$. Roy's Largest Root $(\mathrm{RLR})=\mathrm{R}=\lambda_{\max }$, Where, $\lambda_{i}$ is the eigenvalue of the ith discriminant function. ${ }^{\lambda_{i}}$ can also be written as the ratio of explained to unexplained variances and $\mathrm{n}$ is the total number of discriminant functions (Andy Filed 2009).

\section{REFERENCES}

[1] J. Lockett, "Effective Performance Management: A Strategic Guide to Getting the Best from People," London: Kogan Page Limited, 1992.
[2] M. Armstrong, "Improving Organizational Effectiveness," London: Kogan Page Limited, 1994.

[3] A. Neely, C. Adams, and M. Kennerly, "The Performance Prism: The Scorecard for Measuring and Managing Business Success," London: Pearson Education Limited, 2002.

[4] A. Neely, G. Mike, and K. Platts, "Performance measurement system design: a literature review and research agenda," International Journal of Operations \& Production Management, vol. 15, no. 4, 1995, pp.80-116.

[5] R. Simmons, "Performance Measurement and Control Systems for Implementing Strategy," Upper Saddle River, NJ: Prentice Hall, 2000.

[6] R. Kaufman, S. Thiagarajan, and P. MacGillis, "The Guidebook for Performance Improvement," San Francisco, California: Jossey-Bass/ Pfeiffer Publisher, 1997.

[7] U. A1. Turki and S. Duffuaa, "Performance measures for academic departments," The International Journal of Educational Management, vol. 17, no. 7, 2003, pp.330-338.

[8] R. D. Pritchard, P. L. Roth, S. D. Jones, and P. G. Roth, "Implementing feedback systems to enhance productivity: A practical guide," National Productivity Review, vol. 10, no. 1, 1990, pp.57-67.

[9] A. Neely, G. Mike, and K. Platts, "Performance measurement system design: a literature review and research agenda," International Journal of Operations \& Production Management, vol. 15, no. 4, 1995, pp.80-116.

[10] S. Tangen, "Insights from practice: Analyzing the requirements of performance measurement systems," Measuring Business Excellence, vol. 9 , no. 4, 2005, pp.46-54

[11] C. L. Comm and D. F. X. Mathaisel, "Evaluating teaching effectiveness in America's business schools: Implications for service marketers," Journal of Professional Services Marketing, vol. 16, no. 2, 1998, pp. 163-170.

[12] Annual Report, "Department of School education \& Literacy, Department of Higher Education," Ministry of Human Resource Development, Goverenment Of India, 2010, pp 56-63.

[13] Annual report of the department of higher education, 2009-2010, Government of West Bengal, June, 2010. pp 88.

[14] G. Ghosh, "Problem of plenty: Engineering seats lying vacant in West Bengal," Business Standard, Kolkata, August, 2010.

[15] M. Wisniewski, "Using SERVQUAL to assess customer satisfaction with public sector services," Managing Service Quality, vol.11, no.6, 2001, pp. 380-388.

[16] C. Gronroos, "Service management and marketing: A customer relationship management approach," $2^{\text {nd }} e d n$, John Wiley \& Sons, West Sussex England, 2000.

[17] B. R. Lewis and V. W. Mitchell, "Defining and measuring the quality of customer service," Marketing Intelligence \& Planning, vol. 8, no. 6, 1990, pp. 11-17.

[18] J. A. Dotchin and J. S. Oakland, "Total quality management in services: Part 2 Service quality," International Journal of Quality \& Reliability Management, vol. 11, no. 3, 1994, pp. 27-42.

[19] P. Asubonteng, K. J. McCleary, and J. E. Swan, "SERVQUAL revisited: a critical review of service quality," Journal of Services Marketing, vol. 10, no. 6, 1996, pp. 62-81.

[20] M. Wisniewski and M. Donnelly, "Measuring service quality in the public sector: the potential for SERVQUAL," Total Quality Management, vol. 7, no. 4, 1996, pp. 357-365

[21] A. Parasuraman, V. A. Zeithaml, and L. L. Berry, "A conceptual model of service quality and its implication," Journal of Marketing, vol. 49, fall, 1985, pp. 41-50.

[22] B. Edvardsen, B. Tomasson, and J. Ovretveit, Quality of Service: Making it Really Work, McGraw-Hill, New York, NY, 1994.

[23] E. Babakus and G. Boller, "An empirical assessment of the SERVQUAL scale", Journal of Business Research, vol. 24, May, 1992, pp.253-68

[24] J. Cronin and S. Taylor, "Measuring service quality: a re-examination and extension", Journal of Marketing, vol. 56, July, 1992, pp. 55-68

[25] A. Parasuraman, V. Zeithaml, and L. L Berry, "Refinement and reassessment of the SERVQUAL scale," Journal of Retailing, vol.67, no.4, 1991, pp.420-54

[26] R. C. Lewis, "The measurement of gaps in the quality of hotel services," International Journal of Hospitality Management, vol.6, no. 2,1987 , pp.83-8

[27] M. O’Neill, C. Wright, and F. Fitz, "Quality evaluation in on-line service environments: an application of the importance-performance measurement technique," Managing Service Quality, vol. 11, no.6, 2001, pp.402-417.

[28] L. Harvey, D. Green, "Assessing quality in higher education: a transbinary research project," Assessment and Evaluation in Higher Education, vol. 18, no. 2, 1993, pp. 143-9. 
[29] D. Clewes, “A student-centered conceptual model of service quality in higher education," Quality in Higher Education, vol. 9, no. 1, 2003, pp. 69-85.

[30] M. Marzo-Navarro, M. Pedraja-Iglesias, and M. P. Rivera-Torres, "Measuring customer satisfaction in summer courses," Quality Assurance in Education, vol. 13, no. 1, 2005, pp. 53-65.

[31] P. Sander, K. Stevenson, M. King, and D. Coates, "University students, expectations of teaching," Studies in Higher Education, vol. 25, no. 3, 2000, pp. 309-23.

[32] D. D. Gremler, M. A, McCollough, "Student satisfaction guarantees: an empirical examination of attitudes, antecedents, and consequences," Journal of Marketing Education, vol. 24, no. 2, 2002, pp. $150-260$.

[33] F. Hill, "Managing service quality in higher education: the role of the student as primary consumer," Quality Assurance in Education, vol. 3 , no. 3,1995 , pp. 10-21.

[34] M. Guolla, "Assessing the teaching quality to student satisfaction relationship: applied customer satisfaction research in the classroom," Journal of Marketing Theory and Practice, vol. 7, no. 3, 1999, pp. 87 97.

[35] M. A. O’Neill and A. Palmer, “Importance-performance analysis: a useful tool for directing continuous quality improvement in higher education," Quality Assurance in Education, vol. 1, no. 1, 2004, pp. $39-52$.

[36] F. Abdullah, "The development of HEdPERF: A new measuring instrument of service quality for the higher education sector," Int. J. of Cons. Stud. 30: 569-581, 2006.

[37] M. S. Owlia and E. M. Aspinwall, "A framework for the dimensions of quality in higher education," Quality Assurance in Education, no. 4, 1996, pp. 12-20.

[38] G. Svensson and G. Wood, "A model of Business ethics," Journal of Business Ethics, 2007, 77:303-322

[39] S. V. Scott, "The academic as service provider: is the customer always right?” J. High Educ. Policy. Manage., vol. 21, no. 2, 1999, pp. 193-201.

[40] R. G Jr. Sines, E. A. Duckworth, "Customers service in higher education,” J. Market. High. Educ., vol. 5, no. 2, 1994, pp: 1 - 15.

[41] M. Avdjieva and M. Wilson, "Exploring the Development of Performance in Higher Education," Managing Service Performance, vol. 12, no. 6, 2002, pp. 372-383.

[42] B. R. Barnes, "Analysing Service Performance: The Case of PostGraduate Chinese Students," Issn $n r ., 1743-6796,2006$

[43] P. B. Sakthivel, "TQM implementation and student's satisfaction of academic performance," The TQM Magazine, Emerald Group Publishing Limited, vol. 17, no. 6, 2005, pp. 573-589.

[44] A. Parasuraman, V. A. Zeithaml, and L. L. Berry, "A conceptual model of service quality and its implications for future research," Journal of Marketing, no. 49, 1985, pp. 41-50.

[45] J. B. Ford, M. Joseph, and B. Joseph, "Importance-Performance Analysis as a Strategic Tool for Service Marketers: The Case of Service Performance Perceptions of Business Students in New Zealand and the USA," The Journal of Services Marketing, vol. 13, no. 2, 1999, pp. 171-181.

[46] U. Lehtinen and J. R. Lehtinen, " Service Performance: A Study of Performance Dimensions," Working Paper, Service Management Institute, Helsinki, 1992

[47] C. Grönroos, "Service management and marketing. A customer relationship management approach," Wiley, Chichester, 2000.

[48] G. M. Hampton, "Gap analysis of college students satisfaction as a measure of professional service performance," Journal of professional service marketing, vol. 9, no. 1, 1993, pp. 115-128.

[49] D. Pereda Airey and M. Bennett, "Service Performance in Higher Education: The Experience of Overseas Students," journal of Hospitality, Leisure, Sport and Tourism Education, vol. 6, no. 2, 2007, PP. 55-67.

[50] I. P. S. Ahuja, T. P. Singh, "Strategies for Affecting Performance Improvement in Technical Education," The Indian Journal of Technical Education, vol. 27, no. 1, 2004, pp 56-63.

[51] A. Adee, "Linking Student Satisfaction and Service Performance Perceptions: The Case of University Education," European Journal of Marketing, vol. 37, no. 7, 1997, 528-535.

[52] L. K. Lau, "Institutional Factors Affecting Student Retention, Education," vol. 124, no. 1, 2003, pp. 126-136.

[53] Y. C. Cheng, W. M. Tam, "Multi-models of quality in education," Quality Assurance in Education, vol. 5, no. 1, 1997, pp. 22-31.

[54] J. Pounder, "Institutional performance in higher education: is quality a relevant concept?" Quality Assurance in Education, vol. 7, no. 1/3, 1999 , pp. 156-63.
[55] M. Cave, S. Hanney, and M. Henkel, "Performance Measurement in Higher Education - Revisited. Public Money \& Management," vol. Oct-Dec, 1995, pp.17-23.

[56] H. J. Rubin and I. S. Rubin, "Qualitative Interviewing: The Art of Hearing Data," Sage, Thousand Oaks, CA, 1995.

[57] V. Umashankar and K. Dutta, "Balanced scorecards in managing higher education institutions: an Indian perspective," International Journal of Educational Management, vol. 21, no. 1, 2007, pp. 54 - 67.

[58] S. H. Chen, C. C. Yang, and J. Y. Shiau, "The application of balanced scorecard in the performance evaluation of higher education," The TQM Magazine, vol. 18, no. 2, 2006, pp.190-205.

[59] A. Parasuraman, V. A. Zeithaml, and L. L. Berry, "SERVQUAL: A Multiple-Item Scale For Measuring Consumer Perceptions Of Service Quality," Journal Of Retailing, Spring, vol. 64, no. 1, 1988, pp. 12-40.

[60] A. Parasuraman, V. A. Zeithaml, and L. L. Berry, "Refinement And Reassessment Of The SERVQUAL Scale", Journal of Retailing, Winter, vol. 67, no. 4, 1991, pp. 420-450.

[61] J. M. Carman, "Consumer Perceptions Of Service Quality: An Assessment Of The SERVQUAL Dimensions," Journal Of Retailing, vol. 66, issue 1, 1990, pp. 33-55.

[62] T. J. Brown, G. A. Churchill, and J. P. Peter, "Improving The Measurement Of Service Quality”, Journal of Retailing, vol. 69, no. 1, Spring, 1993, pp. 127-139.

[63] R. Carney, "Building an Image," Paper presented at the Proceedings Symposium for the Marketing of Higher Education, New Orleans, Lousiana: American Marketing Association, 1994.

[64] A. Athiyaman, "Linking student satisfaction and service quality perceptions: The case of university education," European Journal of Marketing, vol. 31, no. 7/8, 1997, pp. 528-540.

[65] H. Lee, Y., Lee, and D. Yoo, "The determinants of perceived service quality andits relationship with satisfaction," Journal of Services Marketing, vol. 14, no. 2/3, 2000, pp. 217.

[66] M. S Sohail and N. M. Shaikh, "Quest for Excellence in Business Education: A Study of Student Impressions of Service Performance," The International Journal of Educational Management, vol. 18, no.1, 2004 , pp. $58-65$

[67] Kwek and L. Choon, “The 'Inside-out' and 'Outside-in' Approaches on Students' Perceived Service Performance: An Empirical Evaluation," Management Science and Engineering, vol. 4 no. 2, 2010, pp. 01-26.

[68] R. Carney, "Building an Image", Paper presented at the Proceedings Symposium for the Marketing of Higher Education, New Orleans, Lousiana: American Marketing Association, 1994.

[69] K. B. Powar and S. K. Panda, " Accreditation as a Means of Performance Assurance in Higher Education," Association of Indian Universities, New Delhi, 1995.

[70] K. Mandal and C. Banerjee, "Development of a construct for measuring the performance of engineering and technology program A confirmatory factor analysis approach," in Proc. International Conference on Business and Information Management, ICBIM 2012.ISBN:978-81-8424-744-2, NIT, Durgapur, India, January 2012 vol. 1,2012 , pp.375-395.

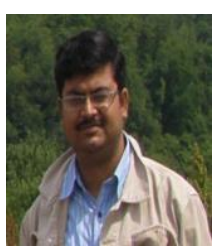

Dr. Kaushik Mandal is currently working as Assistant Professor in the Department of Management Studies at the National Institute of Technology, Durgapur, West Bengal, India. He has done his master and doctoral work in Business Administration. He is an author of several peerreviewed publications on the field of Marketing, Distribution Channel, Brand Management and Service Marketing. He has presented a good number of papers on his research both nationally and internationally. He currently reviews articles for several journals. Dr. Mandal can be contacted at kaushikmandal.nit@gmail.com

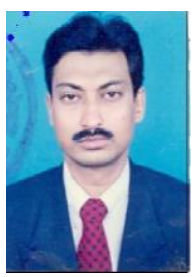

Chandan Kumar Banerjee is presently pursuing his $\mathrm{Ph}$. D under the guidance of Dr. Kaushik Mandal in Department of Management Studies at the National Institute of Technology, Durgapur, West Bengal, India. He has done his master in Business Administration. His area of interest is Service Marketing. He has presented papers in both conferences and journals. Chandan Kumar Banerjee can be contacted at: chandankbanerjee@gmail.com 